\title{
The Relationship between Environmental Sanitation and Helminthes Disease on Primary School Children in Terminal Disposal Waste Area
}

\author{
Evawany Aritonang1, Albiner Siagian² \\ Dept of Public Health Nutrition University of Sumatera Utara \\ Medan, Indonesia \\ evawany@gmail.com¹, albiner_sgn@gmail.com²
}

\begin{abstract}
Helminthes is one of public health problem in Indonesia with a prevalence of $45 \%$. Worms is incident to the entry of worm eggs and infects the human intestine that is generally referred to as soiltransmitted helminthes (STH). Helminthes disease generally more common in toddlers and children of primary school age caused more activity related to land, that the incidence of intestinal worm is closely related to environmental sanitation. Terminal disposal waste area is an area that risk to helminthes due to unhealthy environmental sanitation. This cross sectional study wants to analyze relationship between environmental sanitation and helminthes in 52 primary students as sample. Primary data consist of environmental sanitation and helminthes status. The result showed that $51.9 \%$ primary student have not eligible environmental sanitation such as not all of student have latrine in their home, $46.2 \%$ source of clean water come from wells that is not qualify to healthy. Helminthes prevalence in primary student is $17.3 \%$. There is no significant relationship between environmental sanitation and helminthes status ( $p>0.05)$.
\end{abstract}

Keywords: environmental sanitation, helminthes, primary student, terminal disposal waste area

\section{INTRODUCTION}

Helminthes is one of public health problem in Indonesia with a prevalence of $45 \%$. Worms is incident to the entry of worm eggs and infects the human intestine. The process in which this worm eggs through the soil so that the worm infection is generally referred to as soil-transmitted helminthes (STH). Indonesia basic health research revealed that the prevalence of worm infection in Indonesia was $28.12 \%[1]$. This high prevalence of worm infection is also seen in several studies in Indonesia in the range 15$50 \%[2,3,4]$. The prevalence of worm infestation in the province of Sumatera Utara, more than $10 \%$, whiles for the city of Medan no worm infection prevalence data [5].

Helminthes disease generally more common in toddlers and children of primary school age caused more activity related to land. Land is a cause of transmission of the worm eggs from soil to humans through the hands or nails containing worm eggs and then into the mouth with food or without food [6]. Based on this it was concluded that the incidence of intestinal worm is closely related to environmental sanitation.
Despite the relatively high prevalence of worm infection in Indonesia, but prevention and eradication of helminthes infections has not done optimally. This can be caused due to the impact of worm infections are not seen directly, so less gets enough attention from the government, especially by parents. Based on that soil is a medium of transmission to human intestinal worms then it is very important to consider soil and climate conditions that determine the proliferation of worms. Very humid climatic conditions suitable for the growth and proliferation of worm eggs. It is commonly found in many farming areas or regions where the climate is damp or wet. In the tropics have humidity was so high and deworming is still categorized as a tropical disease.

A landfill (Terminal Disposal Waste Area) is an area classified as areas prone to the incidence of intestinal worms. This is due to the soil moist by watering even the amount of landfill waste so it is very suitable for the breeding of worms that are very vulnerable to the worm infection in children living near the landfill. One landfill in the province of Sumatera Utara is Terjun Landfill in Terjun Village Medan Marelan SubDistrict. Terjun 
landfill is a landfill that accommodates garbage from the 23 districts in the city of Medan. Event delivery of waste to landfill is very active from morning until midnight at 23:00 pm.

Helminthes disease on primary student in the area of the landfill is not yet known. This research wants to analyze how the relationship of environmental sanitation with the incidence of worm infection on primary student around landfills.

\section{MATERIALS AND METHODS}

This research is descriptive analytic design with "cross sectional study". Research will be carried out within a period of six months, from July to November 2016, in Terjun Landfill in Medan Marelan Subdistrict of Sumatera Utara Province. The population is all primary student grades 5 and 6 in school around landfill. There are two schools: government school and private school MIN Darul Ulum School i.e. 86 student. The sample is total population who meet the inclusion criteria such as not suffering from the disease and willing to be sampled by signing an informed consent (willingness as sample). From a population of 86 students who are willing to be sampled are 52 people so the sample size is 52 students.

\section{RESULTS}

\section{Environment Sanitation}

Environmental sanitation in the area of the landfill is generally not good, that $51.9 \%$ are not in accordance with the requirements (conditions) health. Some aspect of environmental sanitation shown in the following table.

Table I. Environmental Sanitation

\begin{tabular}{|l|c|c|}
\hline Environmental Sanitation & $\mathbf{n}$ & $\mathbf{\%}$ \\
\hline Qualify & 25 & 48.1 \\
\hline Not eligible & 27 & 51.9 \\
\hline Total & 52 & 100.0 \\
\hline
\end{tabular}

According to the table II is known that not all primary students have latrines in their homes and there are still $9.6 \%$ of student that the pit is shared pit latrines. This will obviously have an impact on water pollution and air pollution will affect the health of the environment.

Table II. Aspects of Environmental Sanitation

\begin{tabular}{|c|c|c|c|}
\hline No & $\begin{array}{c}\text { Aspect of Environmental } \\
\text { Sanitation }\end{array}$ & $\mathbf{n}$ & $\%$ \\
\hline 1 & $\begin{array}{l}\text { Availability of latrines at } \\
\text { home } \\
\text { - Latrine cubluk } \\
\text { - Latrine goose neck } \\
\text { - No latrine }\end{array}$ & $\begin{array}{c}5 \\
44 \\
3\end{array}$ & $\begin{array}{r}9.6 \\
84.6 \\
5.8\end{array}$ \\
\hline 2 & $\begin{array}{l}\text { Source of water } \\
-\quad \text { Well } \\
-\quad \text { PAM } \\
-\quad \text { River } \\
\end{array}$ & $\begin{array}{c}24 \\
27 \\
1\end{array}$ & $\begin{array}{r}46.2 \\
51.9 \\
1.9\end{array}$ \\
\hline 3 & $\begin{array}{l}\text { Availability of soap in } \\
\text { latrine } \\
\text { - Available } \\
\text { - Not available }\end{array}$ & $\begin{array}{l}36 \\
16\end{array}$ & $\begin{array}{l}69.2 \\
30.8\end{array}$ \\
\hline 4 & $\begin{array}{l}\text { The management of } \\
\text { household waste } \\
\text { - } \text { Buried or Burned } \\
\text { - Exiled to the river } \\
\text { - Collected out and taken } \\
\text { by janitor }\end{array}$ & $\begin{array}{l}42 \\
2 \\
8\end{array}$ & $\begin{array}{c}80.8 \\
3.8 \\
15.4\end{array}$ \\
\hline 5 & $\begin{array}{ll}\text { Equipment } & \text { garbage } \\
\text { disposal } & \\
\text { - Not available } & \\
\text { - Available } & \end{array}$ & $\begin{array}{c}9 \\
43\end{array}$ & $\begin{array}{l}17.3 \\
82.7\end{array}$ \\
\hline 6 & $\begin{array}{l}\text { House floor condition } \\
-\quad \text { Moist and damp } \\
\text { - Dry }\end{array}$ & $\begin{array}{l}23 \\
29\end{array}$ & $\begin{array}{l}44.2 \\
55.8\end{array}$ \\
\hline 7 & $\begin{array}{l}\text { Type of house floor } \\
-\quad \text { Ceramics } \\
-\quad \text { Cement, tile / terrazzo } \\
-\quad \text { Soil }\end{array}$ & $\begin{array}{l}17 \\
25 \\
10\end{array}$ & $\begin{array}{l}32.7 \\
48.1 \\
19.2\end{array}$ \\
\hline
\end{tabular}

Sources of clean water in the home of students are also only $51.9 \%$ are derived from tap water, $46.2 \%$ came from wells that category are also not all wells in accordance with the provisions of the well informed and healthy. In addition there are $19.2 \%$ of elementary school children the floor of the house is ground floor of the house and the condition is often damp and wet. It is risky for the presence of worms that can live and breed so that it can pass on to residents. 


\section{Status of Children Helminthes}

There are different types of worms that there are two types of Ascaris lumbricoides and Trichuiuris trichiura. Among 9 positive worming only one positive person have two types of worms, while 8 others were positive only have one type of worm that is only Ascaris lumbricoides or Trichuiuris trichiura.

Table III. Status Helminthes on School Children

\begin{tabular}{|l|c|c|}
\hline \multicolumn{1}{|c|}{ Worming } & n & \% \\
\hline Positive & 9 & 17.3 \\
\hline Negative & 43 & 82.7 \\
\hline Total & 52 & 100.0 \\
\hline
\end{tabular}

\section{Health Status}

Based on the table IV it is known that $50 \%$ of elementary school children fall ill and $50 \%$ did not suffer pain in the last month. Habits seek treatment when ill also show unfavorable behavior where less than $50 \%$ of elementary school children who go to health care when sick, the behavior of other treatment is to shamans, do not seek treatment, and buy drugs freely. This shows that the health status of primary school children is less good. Similarly, when viewed from drinking-worming note that $84.6 \%$ of elementary school children taking medication worm had been more than a year ago.

Table IV. Health Status

\begin{tabular}{|c|c|c|c|}
\hline No & Health Status & $\mathbf{n}$ & $\%$ \\
\hline 1 & $\begin{array}{l}\text { Health status in one } \\
\text { month ago } \\
\text { - Healthy } \\
\text { - Unhealthy }\end{array}$ & $\begin{array}{l}26 \\
26\end{array}$ & $\begin{array}{l}50.0 \\
50.0\end{array}$ \\
\hline 2 & $\begin{array}{l}\text { Health seeking behavior } \\
\text { - } \quad \text { Shaman } \\
\text { - }\end{array}$ & $\begin{array}{c}4 \\
4 \\
20 \\
24 \\
\end{array}$ & $\begin{array}{r}7.7 \\
7.7 \\
38.5 \\
46.2 \\
\end{array}$ \\
\hline 3 & $\begin{array}{l}\text { The last time a drink- } \\
\text { worming } \\
->1 \text { year } \\
-\quad 7 \text { months }-12 \text { months } \\
-\quad 0-6 \text { months }\end{array}$ & $\begin{array}{c}44 \\
4 \\
4\end{array}$ & $\begin{array}{c}84.6 \\
7.7 \\
7.7\end{array}$ \\
\hline
\end{tabular}

Environmental Sanitation relationship with Helminthes

According to the table $\mathrm{V}$ is known that environmental sanitation elementary school children who qualify more $(84.0 \%)$ were negative rather than positive wormy $(16.0 \%)$. But the environmental sanitation of elementary school children who do not qualify well there are more $(81.5 \%)$ were negative rather than positive wormy (18.5\%). Analysis of environmental sanitation relations with wormy status showed no significant relationship ( $p>0.05)$.

Table V. Environmental Sanitation relationship with Helminthes

\begin{tabular}{|l|c|c|c|c|c|c|c|}
\hline \multirow{2}{*}{$\begin{array}{c}\text { Environm } \\
\text { ental } \\
\text { Sanitatio } \\
\text { n }\end{array}$} & \multicolumn{6}{|c|}{$\begin{array}{c}\text { Positiv } \\
\text { e }\end{array}$} & \multicolumn{2}{|c|}{ Negative } & \multicolumn{2}{|c|}{ Total } & \multirow{2}{*}{ p } \\
\cline { 2 - 7 } & $\mathrm{n}$ & $\%$ & $\mathrm{n}$ & $\%$ & $\mathrm{n}$ & $\%$ & \\
\hline Qualify & 4 & 16. & 21 & 84. & 2 & 100. & 1.0 \\
Not & 5 & 0 & 22 & 0 & 5 & 0 & 0 \\
eligible & 9 & 18. & 43 & 81. & 2 & 100. & \\
Total & & 5 & & 5 & 7 & 0 & \\
& & 17. & & 82. & 5 & 100. & \\
& & 3 & & 7 & 2 & 0 & \\
\hline
\end{tabular}

\section{DISCUSSION}

\section{Environmental Sanitation relationship with Helminthes.}

Analysis of environmental sanitation relations with wormy status showed no significant relationship ( $p>0.05)$. It can be seen from the results of their answers to the questionnaire that has been provided is from the aspect of environmental sanitation majority of respondents own latrines goose neck at home, the majority of clean water source is government facility of water, available soap in the toilet, the majority of household waste management buried and burned.

Based on these statements because the majority of environmental sanitation has been good as has a swan neck latrine at home, the majority of clean water source is government facility of water then it is likely not related to worm infection in primary school children. Therefore environmental sanitation is mostly qualified then this is not related to worm 
infestation. Environmental sanitation also has a dominant role in the provision of an environment that supports children's health. Judging from the cleanliness both personal hygiene and the environment plays an important role in the onset of disease. As a result of lack of cleanliness, the child will often suffer from pain such as worm infestation.

Based on the survey results revealed that primary school children are eligible environmental sanitation more $(84.0 \%)$ were negative rather than positive wormy $(16.0 \%)$. But the environmental sanitation of elementary school children who do not qualify well there are more $(81.5 \%)$ were negative rather than positive wormy $(18.5 \%)$.

Carmen Anthonj et al in their research stated that the provision of clean water, sanitation and personal hygiene is good is an important requirement for preventing the transmission of disease, especially in areas where the land is damp and wet as a source of disease due to the presence of microorganisms and invertebrates other lives either in wet [7]. Another study suggested that the behavior of clean healthy and toilet facilities in school children in Myanmar are not good. This has implications for the state of health of children in schools, $11 \%$ experienced at least one episode of diarrhea, $12 \%$ suffer vomiting, and $12 \%$ suffer diarrhea and vomiting in the period of a week ago [8]

Food safety is the most important determinant of the occurrence of diarrheal disease in children. It is estimated that nearly $70 \%$ of diarrheal disease is caused by contaminated food and the number of microbes are most commonly found in drinking water. Based on this, the food hygiene interventions such as the promotion of cooking and warming food properly, preventing the food from exposure to flies, and washing hands before eating is important to prevent infection [9].

Friscasari, $\mathrm{K}$, et al in their study found that the proportion of worm infestation in the village primary school students in the District Teling Tombariri Minahasa 12.2\% consisting of Ascaris lumbricoides, Ancylostoma duodenale, Trichirs trichura and Oxyuris vermicularis. The study concludes that there is no correlation between environmental sanitation with worm infestation in primary school pupils were seen from the latrine, the type of floor of the house, the availability of clean water and garbage disposal facilities [10].

\section{CONCLUSION}

There is no significant relationship ( $p>$ 0.05 ) with the status of environmental sanitation and worm infestation.

\section{REFERENCES}

Ministry of Health. "The basic health research. Agency for Health Research and Development", 2013

Sitti Chadijah, Phetisya Pamela Frederika Sumolang, Ni Nyoman Veridiana. "Relationship of Knowledge, Behavior, and Environment Sanitation Helminthiases Score in Children with Primary School in the city of Palu". Media Research and Development Vol. 24 No. 1 Reviews, Mar 2014, 50-56, 2014

Sirajuddin and Masni. Anemia in. "Genesis Elementary School Students". Journal of the National Public Health Vol. 9, No. 3, February 2015, 2015

Kundaian F, Jootje M. L. Umboh, Billy J. Kepel. "Relationship Between Environmental Sanitation with worm infestation in Primary School Pupils in Rural Teling Minahasa District of Tombariri". Thesis Faculty of Public Health, University of Sam Ratulangi, 2011

North Sumatra Provincial Health Office. "The Health Profile of North Sumatera", 2012

Carmen Anthonj, Andrea Rechenburg, Thomas Kistemann, "Water, sanitation and hygiene in wetlands. A case study from Swamp theEwaso []Narok, Kenya". International Journal of Hygiene and Environmental Health journal ep hom age: www.elsevier.com/locate/ijheh

Emma R. N. Weaver, Paul A. Agius, Hilary Veale, Karl Dorning, hlang T. Thein, Aung P. Poe, J. I. Freya Fowkes, and Margaret E. Hellard, "Water, Sanitation, 
and Hygiene Facilities and Hygiene Practices Associated with Diarrhea and vomiting in Monastic Schools", Myanmar. Am. J. Trop. Med. Hyg., 95 (2), pp. 278-287, 2016

Joe Brown, Sandy Cairncross, Jeroen H J Ensink, "Water, sanitation, hygiene and enteric infections in children", Arch Dis Child 2013; 98: 629-634. doi: 10.1136 / archdischild-2011-301528. Downloaded from http://adc.bmj.com/ on October 24, 2016 - Published by group.bmj.com, 2013

Faust EC, Russel PF. Craig and Faust. "Clinical Parasitology. In: 7th Edition", USA Philadelphia: Lea Febiger Philadelphia 7; 1964: 341-429, 1964. 